\title{
高温埋設管の土壤中における腐食
}

福谷英二** 筧 建 彦** 海野武人**

\section{Corrosion of Underground Hot Water Pipeline}

\author{
Eiji Fukutani, Takehiko Kakehi and Takehito Umino
}

An unusually rapid corrosion leakage occurred in an underground hot spring water pipeline in a volcanic area within about half a year after its laying. The field survey and laboratory tests showed that the abnormal corrosion of the hot water pipeline would have been caused from original macrocorrosion cells, large difference in resistivity due to the differ- ence of moisture contents between upper and lower soil parts round the hot pipe and formation of magnetite on the pipe surface because of the high temperature and the alternative dry and wet condition. As for the protective measures epoxy coating and cathodic protection were studied, and their combination appeared very effective.

\section{1. 緒}

某火山性温泉地带で $80^{\circ} \mathrm{C}$ の高温 熱湯を送る内径 $350 \mathrm{~mm}$, 肉厚 7.9 $\mathrm{mm}$, 延長 $4,200 \mathrm{~m}$ の地下埋設管 が埋設後約 7 カ月間で始点から約 $1,600 \mathrm{~m}$ の地点で外面腐食による穿 孔漏洩を生じた。管にはジンクリッ チ塗料を膜厚 $10 〜 15 \mu$ に塗装し, $1 \mathrm{~mA} / \mathrm{m}^{2}$ の電流密度で 2 カ所の外 部電源防食装置による院極防食を併 用する計画であったが，実際には約 $0.2 \mathrm{~mA} / \mathrm{m}^{2}$ で管路電位 $-900 \mathrm{mV}$ ( $\mathrm{SCE})$ より卑な電位であったもの で穿孔時には $-400 \mathrm{mV}$ 付近にな っていた。

この報告は, 本管の異状腐食原因の究明と対策立案の ために行なわれた現地調査と実験室における試験の結果 を取りまとめたものである。

\section{2. 実施した調査および試験の内容}

\section{$2 \cdot 1$ 現地調査}

a）管路沿い各点にお汓る腐食状況調查

掘サク，超音波厚み計による厚さ測定および腐食ピッ ト深さの測定

b ）大地比抵抗扣よび土質分布の測定, 調査

L-10 型大地比抵抗測定器により $50 \mathrm{~m}$ 間隔に測定, 深 度はー1 $\mathrm{m}$ 扣よびー $3 \mathrm{~m}$

c）電気防食電流の増強試験

* 昭和41年11月17日第13回腐食防食討論会（松山）飞おいて発表, 昭和 42 年 6 月 23 日学振第 97 委員会会議 (東京) 飞掝いて講演

** 中川防蝕工業(株) (東京都千代田区神田鉣治町 2-1)

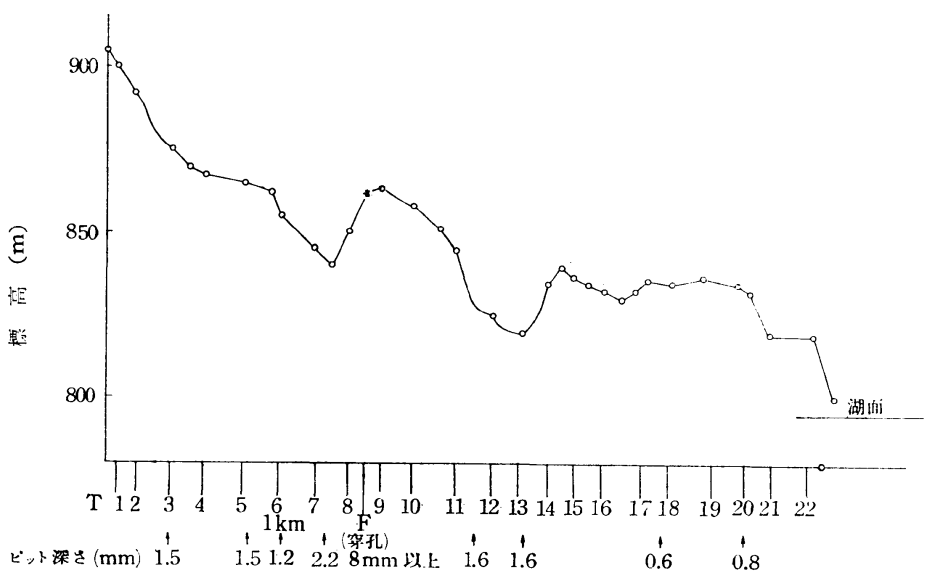

図 1 管路の勾配と孔食の深さ

d）テストピースによる腐食試験およで通電分極試験

e ）管囲周の電位変化測定

f ) 塗覆装材料試験一エポキシ樹脂系塗料の経時劣化 状況調查

\section{$2 \cdot 2$ 実験室試験}

a ）現地土壌および一般土壤中に打ける裸鋼板および 塗装鋼板の腐食試験一冠水状態と乾燥・湿潤のサイクル 繰り返しの場合

b ） a の条件下での電位変化

c）陰極防食試験

\section{3. 調查試験結果および考察}

さく孔漏洩を生じた点（以下F点と称す）の侵食度は $16 \mathrm{~mm} / \mathrm{yr}$ で極端に大きい值である。他の部分について も22カ所で掘さく調査が行なわれたが, 局部的には相当 深い孔食 (1.2〜 $4.4 \mathrm{~mm} / \mathrm{yr})$ を生じているところがあっ 


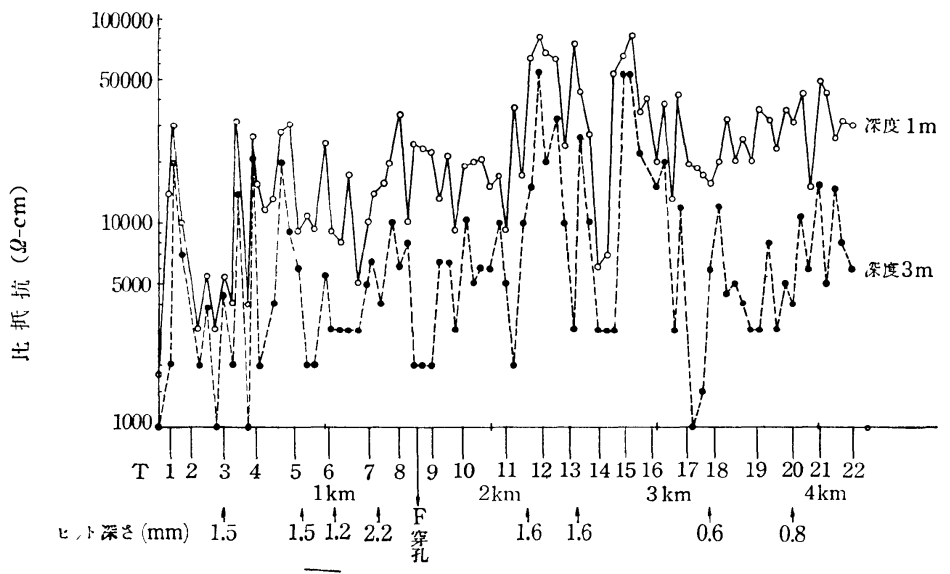

図 2 土鎧の比抵抗分布

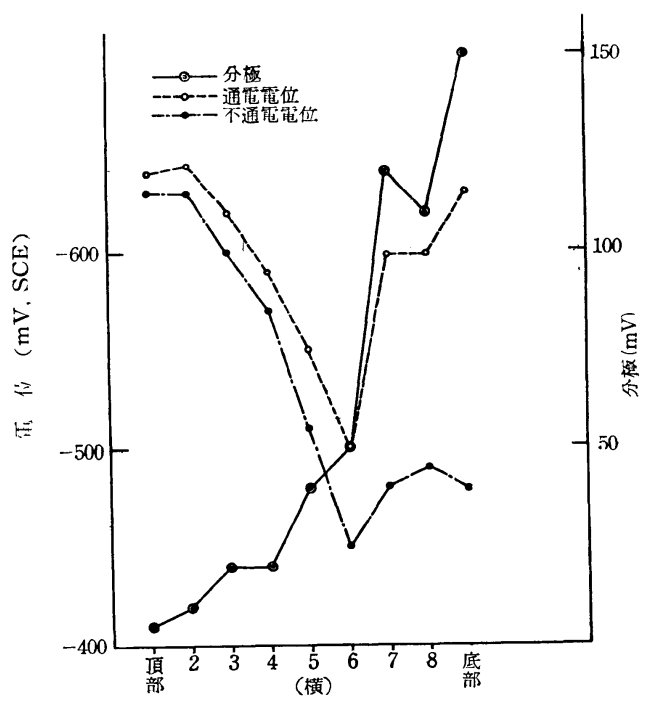

図 3 管の円周方向の電位

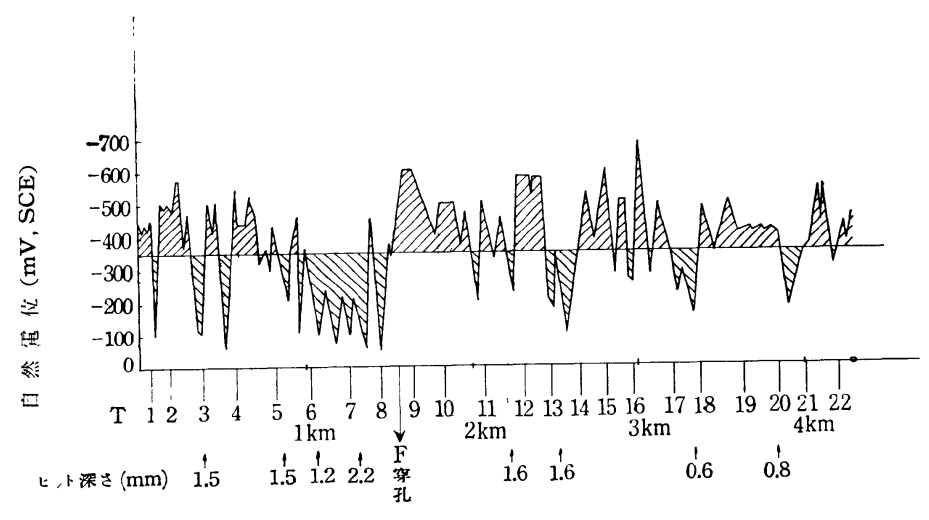

図 $480^{\circ} \mathrm{C}$ 管路の自然電位
た。管路の勾配および孔食の大きい 部分の值を図 1 に示した。この図か ら山地の谷の部分が大きい孔食を生 ずる傾向のあることが観察された。 管路沿いの土堙比抵抗は図 2 に示す ようにわずか $2 \mathrm{~m}$ の深度の差で比抵 抗が著しく異なる。これは高温環境 土壤の特質ともいらべき点であろ 5。上下の比抵抗差の大きい地点で 孔食が大きく現われている。

図 3 は孔食が比較的小さい地点 （ターミナル No. 9) 付近の管周囲 の電位状況を示したものであるが， 管の頂部と底部では自然電位で約 $140 \mathrm{mV}$ の電位差があり，頂部の電 位が卑である。この場合管の上面の 電位の卑な方に孔食がある。図4 は 管路沿いの自然電位の変化状況を示 した。電位の起伏ははなはだしく, 電位の貴な部分に大きい孔食を生じ ている。

図3では卑な部分に孔食があり図 4 では電位の貴な部分に孔食が出る が，その意味は次のよ5に解すべき であろう。すなわち, タ一ミナル No.9 付近は管の電位が比較的卑で 孔食の小さい部分に属するが，その 部分を詳細に調査すれば管の上下で 局所的なマクロ電池を生じそのマク 口電池内では電位の卑な部分が陽極 となって孔食を生ずるのであろう。

実験室および現地で行なった腐食 試験結果を表 1 に示した。表 1 には 九工試の試験結果1)も同時に示した。

九工試の実験室試験は $75^{\circ} \mathrm{C}$ で終 始湿潤状態を保持したもので，中川 防蝕の侵食度は陰分極曲線から求め たものである。これらの数値は同一 土壤を用いたものであるが，両者の 結果にはかなりの差が見られる。こ の試験結果から次のようなことが考 えられる。

a ）高温土壌中での侵食度は大き い。

b ）常時湿潤状態で試験すれば比 較的侵食度は小さい。

c）現地では乾湿を繰り返すため, 
表 1 侵食度 $(\mathrm{mm} / \mathrm{yr})$ 㧊よび最大孔食度 $(\mathrm{mm} / \mathrm{yr})$

\begin{tabular}{|c|c|c|c|c|c|c|c|c|c|c|c|c|}
\hline \multirow{3}{*}{$\begin{array}{c}\text { 試料採取 } \\
\text { ターミナル } \\
\text { No. }\end{array}$} & \multirow{3}{*}{$\mathrm{pH}$} & \multirow{3}{*}{$\begin{array}{c}\text { 此 抵 抗 } \\
\Omega-\mathrm{cm}\end{array}$} & \multicolumn{5}{|c|}{ 実 験 室 試 験 $\quad\left(75^{\circ} \mathrm{C} \sim 80^{\circ} \mathrm{C}\right)$} & \multicolumn{5}{|c|}{ 現 地 埋 設 試 験 } \\
\hline & & & 裸 鈳 & 板 & \multicolumn{2}{|c|}{ 華”プコート } & 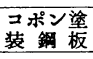 & \multicolumn{2}{|c|}{ 裸 鋼 板 } & \multicolumn{2}{|c|}{ 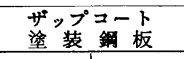 } & \multirow{2}{*}{$\begin{array}{l}\begin{array}{l}\text { 最大孔 } \\
\text { 食 度 }\end{array} \\
\text { 九工試 }\end{array}$} \\
\hline & & & 九工武 & 中 川 & 九工武 & 中 川 & 中 川 & 九工試 & 中 川 & 九工武 & 中 川 & \\
\hline 1 & (4.28) & $(4,050)$ & & 0.35 & & & & & & & & \\
\hline 2 & 5.6 & 26,000 & 0.06 & & 0.08 & & & 0.118 & & 0.08 & & 1.20 \\
\hline 3 & (4.7) & $(1,250)$ & & 1.05 & & 1.8 & 0.011 & 0.317 & & 0.11 & & 5.80 \\
\hline 5 & 5.2 & 5,500 & 0.055 & & 0.05 & & & 0.144 & & 0.07 & & 1.00 \\
\hline 7 & (5.55) & $(12,500)$ & & 0.31 & & & & & & & & \\
\hline $7 \sim 8$ 間 & 6.4 & 22,000 & 0.043 & & 0.01 & & & 0.066 & & 0.06 & & 1.20 \\
\hline $\mathrm{F}$ 黒 & 5.2 & $\begin{array}{l}(1,070) \\
5,400\end{array}$ & 0.120 & & 0.11 & & & 0.952 & 0.31 & 0.33 & 0.30 & $>13.60$ \\
\hline F 褐 & 5.9 & 32,000 & 0.130 & 3.01 & 0.07 & 2.3 & & & & & & \\
\hline 9 & 5.3 & $\begin{array}{l}(22,000) \\
20,000\end{array}$ & 0.041 & 0.27 & 0.11 & & & 0.049 & & 0.06 & & 孔食なし \\
\hline 13 & $\begin{array}{l}(6.4) \\
5.5\end{array}$ & $\begin{array}{c}(225,000) \\
2,000\end{array}$ & 0.041 & & 0.06 & & & 0.075 & 0.016 & 0.08 & 0.013 & 0.80 \\
\hline 16 & 5.8 & $\begin{array}{l}(22,000) \\
12,000\end{array}$ & 0.067 & & 0.08 & & & 0.403 & 0.27 & 0.17 & 0.23 & 4.40 \\
\hline 20 黒 & 5.1 & $\begin{array}{l}(33,000) \\
80,000\end{array}$ & 0.071 & 0.22 & 0.10 & & & 0.460 & & 0.27 & & 5.20 \\
\hline 20 褐 & 5.6 & 25,000 & 0.060 & & 0.08 & & & & & & & \\
\hline .上尾 & (6.85) & $(38,000)$ & & 0.44 & & 0.32 & 0.014 & & & & & \\
\hline
\end{tabular}

備考：(1) 中川の侵食度は通電試験で求めたるのである

(2) $\mathrm{pH}$ および比抵抗の（）は中川社測定, 他は九工試測定

（3）黒・褐はそれぞれ黒色土, 褐色土を示す

か侵食度がきわめて大きい。

d）陰分極曲線から求めた侵食度はかなり現地腐食に 近い值を示すようである。

e ）土質によって侵食度, 最大孔食度に著しい差があ

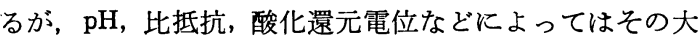
差を生ずる原因を説明できない。フミン酸などの化学物 質の存在や含水量, 透水度などの物理的要素が関係する ものと思われる。

f ）ジンクリッチ塗料の塗装によって現地の侵食度は 約半減されるが，常時湿潤状態ではやや侵食度を増す傾 向にある。

現地試験を通じて得られたこれらの結果を確認するた めに実験室試験を行なった。

図 5 は実験室のある埼玉県上尾市のローム質土堙を用 いて，冠水状態と冠水状態から $80^{\circ} \mathrm{C}$ に保ったまま自然 に乾燥させたときの，侵食度と自然電位との時間による 変化を示したもので, 乾燥によって自然電位は貴に移行 し，侵食度は著しく大となる。

図 6 は毎日冠水と乾燥を繰り返して行なった場合の自 然電位の変化状況を示すもので，乾燥で貴になった自然 電位は注水によって卑に回復するが回復度は乾燥を繰り 返すごとに減じ，1 週間後にはほとんど回復しなくなる。

図 7 は乾湿の周期をそれぞれいろいろに変えた場合の 侵食度に及ぼす影響を調べたもので，乾湿の周期が頻繁 なほど侵食度は大となる。

図 8 は各種の状態に和ける侵食度を比較したもので, $80^{\circ} \mathrm{C}$ に和ける乾湿絽り返しのある土壌中ではいかに常 温の土壤中より侵食度が大きいかがよくわかる。

乾湿繰り返しを行なって鋼表面の腐食生成物はX線回

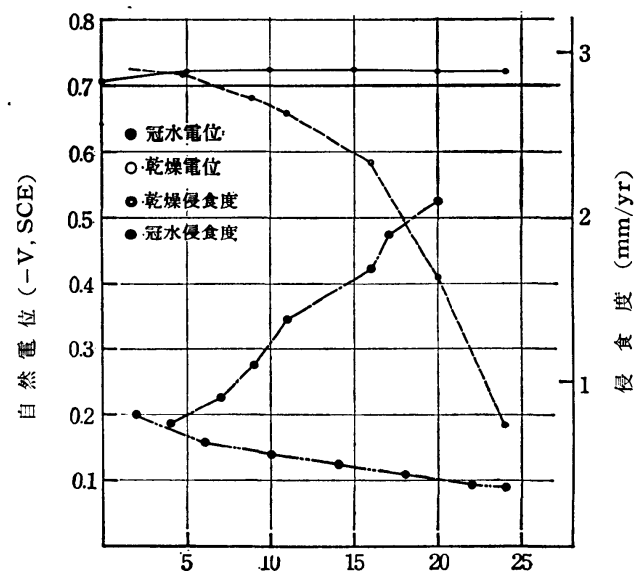

時 間 $(\mathrm{hr})$

図 $580^{\circ} \mathrm{C}$ 赤褐色口一公質土壤（上尾）

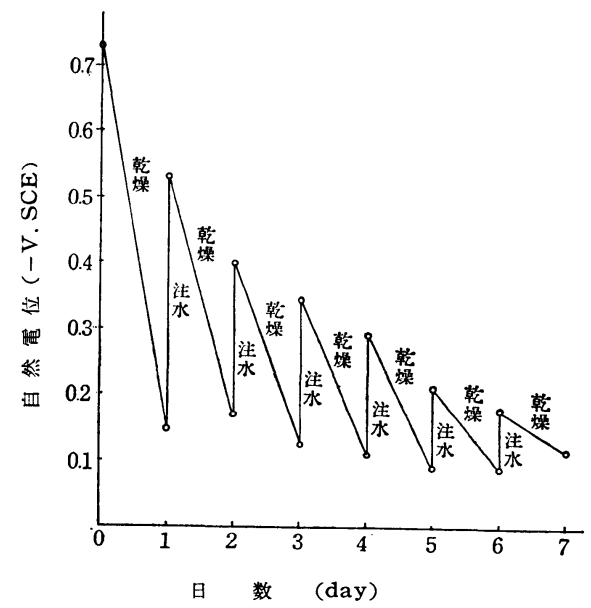

図 $680^{\circ} \mathrm{C}$ 茶褐色口-ム質土㖶（上尾） 乾湿繰り返し自然電位 


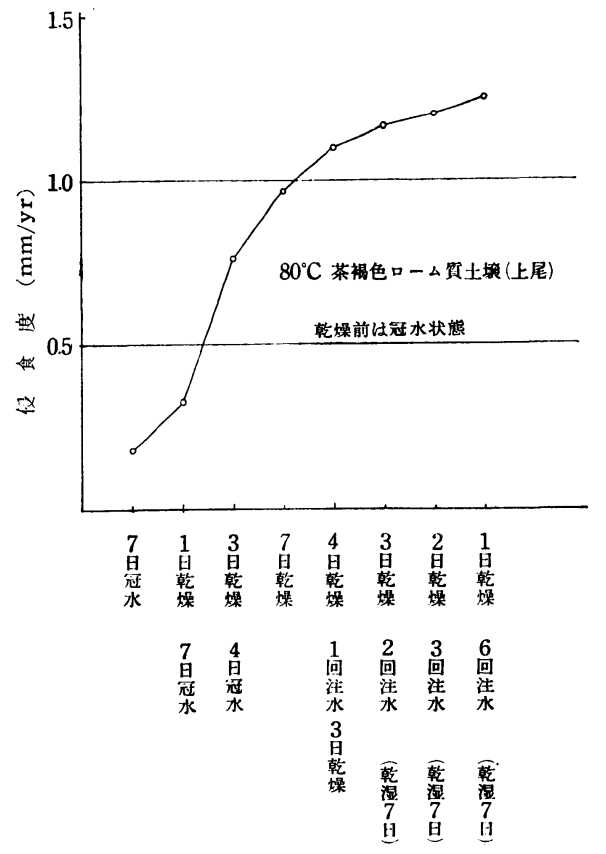

図 7 乾湿繰り返し方法の影響

折によれば表層は主として赤褐色の $\alpha-\mathrm{Fe}_{2} \mathrm{O}_{3}$ と $\mathrm{Fe}_{3} \mathrm{O}_{4}$ でありその下層に黒色の $\mathrm{Fe}_{3} \mathrm{O}_{4}$ が生成していた。

表 2 は現地土壤打よび上尾土壤中に打ける裸鋼の侵食 度と塗装による防食効果を調べたるのである。裸鋼の腐 食はやはり冠水の場合よりも乾湿を繰り返した場合の方 が 5 10 倍大きく, 現地の火山性土壌の方が上尾の土堙 よりやや腐食性大であることがわかる。

ジンクリッチ塗装は冠水状態では裸鋼板より侵食度が 大きいが乾湿繰り返し状態ではかなりの防食効果を示し ている。コポンA（エポキシ樹脂塗料）は防食効果が大 きい。

陰極防食の効果を図 9 扣よび前掲の図 3 亿示した。高 温管でも陰極防食は可能であるが, 電流密度は高く, 特 飞乾湿繰り返しの状態ではかなりの大電流密度でも防食

表 2 腐食試験成績 $\left(80^{\circ} \mathrm{C}\right)$

\begin{tabular}{|c|c|c|c|c|c|}
\hline 土境 & 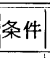 & 試＼cjkstart験 & 重量 & $\begin{array}{l}\text { 侵 度 } \\
(\mathrm{mm} / \mathrm{yr})\end{array}$ & 表面状態 \\
\hline \multirow{4}{*}{$\begin{array}{l}\text { 火 } \\
\text { 山 } \\
\text { 地 } \\
\text { 带 }\end{array}$} & 冠 & 裸鋼 & 0.811 & 0.263 & 全面腐 食 \\
\hline & & ジンクリッチ塗装 & 1. 460 & 0.543 & 白さび \\
\hline & 水 & コポン滁 装 & +0.048 & - & s $<$ れ \\
\hline & 軲 & & 4. 197 & 1. 369 & 粗な全面腐食 \\
\hline \multirow[t]{2}{*}{$\$ 3$} & & ジンクリッチ塗装 & 0.717 & 0.267 & 白さび \\
\hline & 湿 & コポン塗 装 & 0.050 & - & S \\
\hline \multirow{3}{*}{ 上 } & 冠 & 裸銅 板 & 0.315 & 0.103 & 全面腐 食 \\
\hline & & ジンクリッチ塗装 & 0.316 & 0.119 & 白さび \\
\hline & 水 & コポン染 装 & 0.022 & - & ふ心 く れ \\
\hline \multirow{3}{*}{ 尾 } & 乾 & & 3.667 & 1.188 & 粗な全面腐食 \\
\hline & & ジンクリッチ染装 & 0.019 & 0.007 & 白さび \\
\hline & 湿 & コポン淮装 & 0.035 & - & S \\
\hline
\end{tabular}

郡事：府全期間 $308 \mathrm{hr}$ ジンクリッチ膜厚 $20 \mu$
乾湿はこの期間に 3 サイクルとした コポン膜厚 $60 \mu$
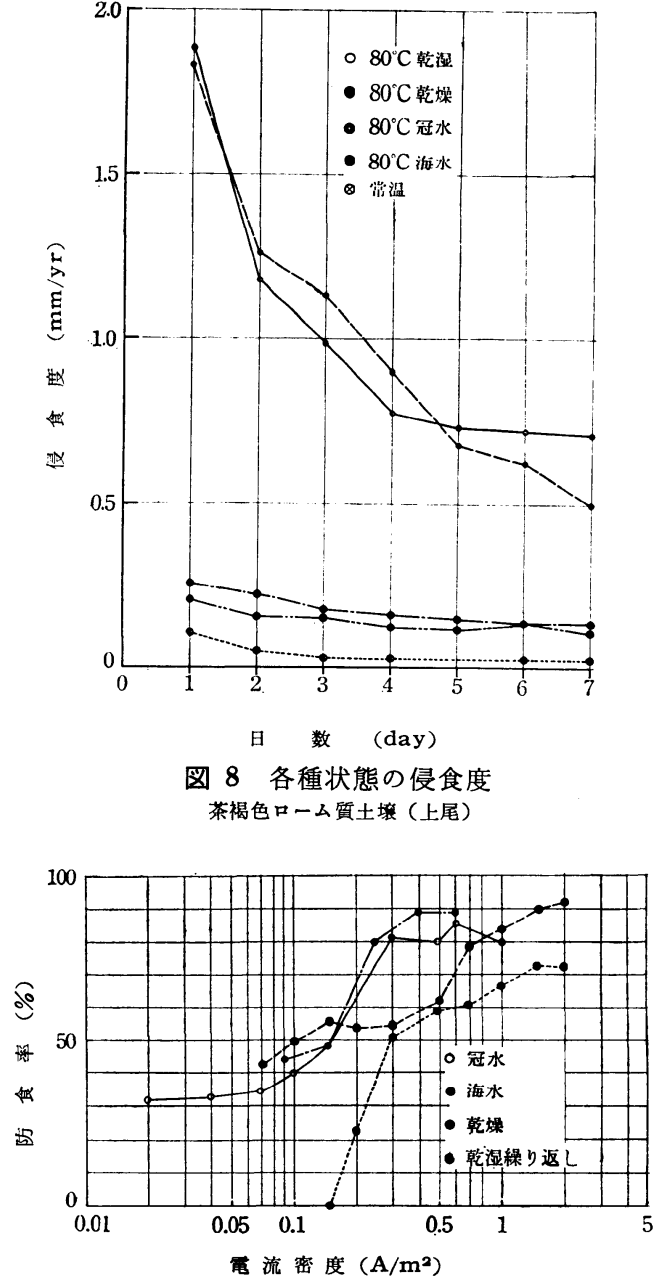

図 9 陰 極防 食 $の$ 効 果

$80^{\circ} \mathrm{C}$ ，赤褐色口一公質土㜔（上尾） $80^{\circ} \mathrm{C}$ 人工海水

率は $70 \%$ 程度である。図 3 は通電によってマク口腐食 が軽減される状況を示している。

コポンAを $60 \mu$ の厚さに塗装して管の電位を -850 $\mathrm{mV}, \mathrm{SCE}$ に保持するに必要な電流密度は $5 \sim 10 \mathrm{~mA} / \mathrm{m}^{2}$ で裸管の場合よりはるかに小さいが，常温叙覆装管の場 合よりははるかに大きいのでエポキシ樹脂コーチングを しても陰極防食の併用は必要と考える。ジンクリッチ塗 装をしても所要防食電流密度はあまり大幅に減少しない ことがわかった。

図 10 は現地の熱湯管の陰極防食による分極状態を示 したものであるが，自然電位から $200 \mathrm{mV}$ 以上陰分極す る範囲はグランドベッド（電極点）からその付近全長 250〜 $500 \mathrm{~m}$ の範囲にすぎない。その範囲内にも点々と 分極の小さい地点が点在している。このときの電流密度 は 40 $80 \mathrm{~mA} / \mathrm{m}^{2}$ である。F 地点に扮ける大きな陰分極 はこの地点にグランドベッドを新設し，管にはエポキシ 
樹脂コーチングを行なったためであ る。

Sudrabin2) は高温管に陰極防食はき かないといっているが，これは常温管 に対するような低電流密度ではきかな いと解すべきで，絶対にきかないとい う意味ではないと思う。

Rogers $\left.{ }^{3}\right)$ は冠水状態にある銅と電気 的に接続されているコンクリート中の 蒸気管は $25 \mathrm{~mA} / \mathrm{ft}$ (推定 $100 \mathrm{~mA} / \mathrm{m}^{2}$ ) で有効に防食されたとしている。

\section{4. 結 論}

高温埋設管の腐食および防食につい て種々調査研究した結果, 不明の点も まだ多々あるが，一般に次のことがいえる。

a ) 高温土㙋中でも常時湿潤状態のときは高温海水中 の腐食と大差はない。

b ）高温環境土壤中で管表面が乾燥過程にあるときま たは乾湿繰り返し状態にあるときは侵食度が著しく大と なる。

c ）高温管では周囲土猿の温度差や乾燥状態の差によ り深さ方向の土壌抵抗が著しく異なるため, 通常埋設管 に起こりやすい延長方向のマクロ腐食だけでなく円周方 向にもマクロ電池を生じ管上側に孔食を生じやすい。

d）高温管では自然電位の貴な部分に深い孔食を生じ や寸い。これは管の表面にマグネタイトが生成するため であると考えられる。

e ）高温管では布設勾配が大きい部分では孔食が少な く, 谷部や平坦部では深い孔食が生じやすい傾向がある。

f）高温管の腐食は土質に左右されることが大きく, また土質差によるマク口腐食も大きいが，どのような土 質成分が腐食に影響を与えるかはつまびらかでない。

g ）管路埋戻しの際, 管路と土裹との間に空洞がある 場合には空洞の周辺に激しい孔食が起こっていることが

観察された。管路はまず砂または細かく砕いた土で埋戻 しを行ない, 空洞部分が生じないように注意することが 大切である。

h ） $80^{\circ} \mathrm{C}$ 以下の管ではエポキシ系の塗装を $60 \sim 100 \mu$ の膜厚で施工し, $10 \mathrm{~mA} / \mathrm{m}^{2}$ 程度の陰極防食を併用する ことが有効であろうと思う。

\section{5. 謝 辞}

この調査ならびに試験に協力された中川防蝕工業（株） 研究開発課 武藤 憲司, 福沢 秀刀, 阿部 喬, 技術 サービス課 落合 直隆, 河内 進の諸氏ならびに有益 なご助言をいただいた九州工業技術試験所長 重野隼太 博士に心から謝意を表します。

(昭和 43 年 1 月 8 日受理)

1）火山系土燷による炭素鋼の異常な腐食 重野隼太, 斎藤明夫：第 13 回腐食防食討論会予稿集（昭和 41 年）

2) L.P.Sudrabin: Cathodic Protection is not Always Successful on Ferrous Structures. Mater. Prot., 5, No. 2, 47 50 (1966) Feb.

3) P.C.Rogers \& E.E.Gross : Cathodic Protection of Underground Heating Lines. Mater. Prot., 1, No.7, 38 42 (1962) July 